This is an electronic reprint of the original article. This reprint may differ from the original in pagination and typographic detail.

Author(s): Salo, Markus; Frank, Lauri

Title: User behaviours after critical mobile application incidents : the relationship with situational context

Year: $\quad 2017$

Version:

Please cite the original version:

Salo, M., \& Frank, L. (2017). User behaviours after critical mobile application incidents : the relationship with situational context. Information Systems Journal, 27(1), 5-30. https://doi.org/10.1111/isj.12081

All material supplied via JYX is protected by copyright and other intellectual property rights, and duplication or sale of all or part of any of the repository collections is not permitted, except that material may be duplicated by you for your research use or educational purposes in electronic or print form. You must obtain permission for any other use. Electronic or print copies may not be offered, whether for sale or otherwise to anyone who is not an authorised user. 
This is the final draft of the article published in Information Systems Journal:

Salo, M. \& Frank, L. (2017). User Behaviours After Critical Mobile Application Incidents: The Relationship with Situational Context. Information Systems Journal, 27(1), 5-30.

\title{
User Behaviors After Critical Mobile Application Incidents: The Relationship with Situational Context
}

\author{
Markus Salo and Lauri Frank \\ Faculty of Information Technology, University of Jyvaskyla, Finland
}

\begin{abstract}
Users occasionally have critical incidents with information systems (IS). A critical IS incident is an IS product or service experience that a user considers to be unusually positive or negative. Critical IS incidents are highly influential in terms of users' overall perceptions and customer relationships; thus, they are crucial for IS product and service providers. Therefore, it is important to study user behaviors after such incidents. Within IS, the relationships between the situational context and user behaviors after critical incidents have not been addressed at all. Prior studies on general mobile use as a related research area have recognized the influence of the situational context, but they have not covered the relationships between specific situational characteristics and different types of user behaviors. To address this gap, we examine 605 critical mobile incidents that were collected from actual mobile application users. Based on our results, we extend current theoretical knowledge by uncovering and explaining the relationships between specific situational characteristics (interaction state, place, sociality, and application type) and user behaviors (use continuance, word-of-mouth, and complaints). We have found, for example, that users are less likely to engage in negative behaviors after negative incidents that take place outdoors or in vehicles than after indoor incidents. This is because users often consider indoor environments to be familiar and treat them with established expectations and low uncertainty: users are accustomed to the notion that the applications function indoors just like before. Further, we present practical implications for mobile application providers by suggesting to them which positive critical incidents are the most beneficial to promote and which negative critical incidents are the most crucial to avoid.
\end{abstract}

Keywords: critical incident, context, use continuance, word-of-mouth, complaints, mobile service 


\section{Introduction}

Single-use experiences of information systems (IS) comprise one of the building blocks of users' overall IS product and service perceptions. A single experience "can be articulated or named," "has a beginning and an end," and "is schematized with a particular character in one's memory" (Forlizzi \& Battarbee 2004, p. 263). A critical incident is defined as a single experience which a person perceives to be "unusually positive or negative" (Edvardsson \& Roos 2001, p. 253): it exceeds a desired level of performance in positive cases, but does not reach an acceptable level of performance in negative cases (Johnston 1995). In this article, we focus solely on critical incidents in product and service usage, even though critical incidents can also reflect other human experiences (e.g., organizational events). As an example of a positive critical incident, a mobile application could enable a surprising discovery of a good, old friend living in the same neighborhood. As an example of a negative critical incident, a person could fail to do a trade and lose a great deal of money because of poor functionality of a mobile device. Detailed examples of actual users' critical mobile incidents are available in Appendix A.

Researchers have presented arguments for the importance of studying critical incidents in terms of research and practice. First, critical incidents are typically highly powerful and influential in human behavior (Flanagan 1954). For example, one crucially negative incident may overrule a set of ordinary positive incidents and lead to discontinued use of a service or a product (Cenfetelli 2004). Second, critical incidents play a central role in forming customer relationships and user perceptions of products, services, and their providers (Edvardsson \& Strandvik 2000; Payne, Storbacka \& Frow 2008). Third, studying critical incidents can enable researchers to achieve "rigor and relevance" (Serenko \& Turel 2010, p. 182).

In service research, critical incidents have been a popular focus (for an overview, cf., Gremler 2004). With usage related to IS, studies have examined critical incidents of self-service technologies (Meuter et al. 2000), websites (Sweeney \& Lapp 2004), online shopping (Holloway \& Beatty 2008), online transactions (Massad, Heckman \& Crowston 2006), online travel services (Serenko \& Stach 2009), email (Serenko 2006; Serenko \& Turel 2010), and mobile services (Gummerus \& Pihlström 2011; Salo et al. 2013). These IS-related studies offer interesting insights about the antecedents of critical incidents, but they are completely missing the link between the situational context and post-experience behaviors.

Studying this link is essential, since prior studies on mobile use in general, as a related research area, have recognized the importance of the situational context for user behaviors (Liang \& Yeh 2010; Liu \& Li 2011; Mallat et al. 2008, 2009; van der Heijden, Ogertschnig \& van der Gast 2005; Wang \& Yi 2012; Yang et al. 2012). Previous studies have presented the direct relationship between the situational context and user behaviors: it has been clearly shown that future behavioral intentions are affected by situational characteristics (e.g., Liu \& Li 2011; Yang et al. 2012). The effect is based on various situational characteristics, such as the users' situational state (e.g., task-specificity), physical surroundings (e.g., place), social environments (e.g., collaboration), and technology characteristics (e.g., interface), which all may increase or decrease future behavioral intentions (Liu \& Li 2011; Xu \& Yuan 2009; Yang et al. 2012). 
For example, Yang et al. (2012) present that mobile users may behave differently at home when compared to other environments due to the different availability of substitute technologies. However, previous studies have either treated the situational context as only one abstract construct or considered only one type of user behavior. Therefore, there is a gap in research regarding the relationships of specific situational characteristics and different types of post-experience behaviors.

As the first step in closing this gap, we examine 605 actual critical incidents of mobile Internet applications collected with the critical incident technique (CIT). CIT fits the purpose of our study since it is suitable for gaining insights on an undiscovered phenomenon (Gremler 2004; Meuter et al. 2000). A mobile Internet application is defined as software that applies an Internet connection and is installed on a mobile or tablet device. There are many reasons why studying user behaviors related to mobile applications is especially essential: there often exist several alternative services to which it is easy for users to switch (Zhou 2011); users react differently with mobile services than with other IS as they, for example, tend to be more impulsive and demand time criticality (Anckar \& D'Incau 2002); and the enormous growth of mobile use is expected to continue (Morgan Stanley Research 2011).

Given the importance of the topic and the context, the aim of this study is to contribute by providing a theoretical understanding of the relationships between situational characteristics (namely, interaction state, place, sociality, and application type) and post-experience behaviors (namely, use continuance, word-of-mouth, and complaints). Based on our new findings, we develop a research model to uncover the nature of the relationships and explain them theoretically. We also discuss practical implications by specifying certain types of critical incidents on which application providers should focus to achieve desired user behaviors.

\section{Related Work and Conceptual Foundation}

This study attempts to produce new knowledge from the perspective of two aspects. First, research on critical IS-related incidents, an important topic itself, completely lacks an understanding of the relationships between the situational context and post-experience behaviors. Second, a stream of research regarding mobile use in general has found such a relationship to exist on an abstract level, but has not yet covered what kind of relationships precise situational characteristics have with different types of user behaviors and why. We elaborate upon these two points further as follows.

\section{Studies on Critical IS-related Incidents}

We defined inclusion criteria for reviewing relevant studies on critical IS-related incidents, as suggested by Webster and Watson (2002). To be included in the review, a research article needed to study critical incidents of IS products and services, as single-use experiences or usage situations. One of the authors then searched for such research articles published in journals and conference proceedings. To doublecheck and complement the search, we assigned the topic of our study to an IS student who worked on a 
thesis and a group of five students participating an IS research methods course. One of the authors instructed the students about the inclusion criteria, keywords, and sources. The related work is summarized in Table 1. In the following paragraphs, we first present a brief history of research related to critical incidents and then elaborate more on the four studies that include some examination of user behaviors after critical incidents.

\begin{tabular}{|c|c|c|c|c|c|}
\hline \multicolumn{6}{|c|}{ Table 1. Studies on Critical IS-related Incidents } \\
\hline Study & Topic/context & $\begin{array}{l}\text { Positive or } \\
\text { negative } \\
\text { incidents }\end{array}$ & $\begin{array}{l}\text { Investig } \\
\text { Post- } \\
\text { experience } \\
\text { behaviors... }\end{array}$ & $\begin{array}{l}\text { ion of: } \\
\text {...and the } \\
\text { situational } \\
\text { context }\end{array}$ & Relevant Findings \\
\hline $\begin{array}{l}\text { Sweeney \& } \\
\text { Lapp (2004) }\end{array}$ & $\begin{array}{l}\text { Quality perceptions } \\
\text { on websites }\end{array}$ & Both & No & No & $\begin{array}{l}\text { Ease of use, content, and process affect } \\
\text { service quality. }\end{array}$ \\
\hline $\begin{array}{c}\text { Massad, } \\
\text { Heckman \& } \\
\text { Crowston } \\
\text { (2006) }\end{array}$ & $\begin{array}{l}\text { (Dis)satisfaction } \\
\text { with electronic } \\
\text { services }\end{array}$ & Both & No & No & $\begin{array}{l}\text { Some sources are more likely to satisfy } \\
\text { than dissatisfy and vice versa. }\end{array}$ \\
\hline $\begin{array}{l}\text { Holloway \& } \\
\text { Beatty (2008) }\end{array}$ & $\begin{array}{l}\text { (Dis)satisfaction } \\
\text { with Internet } \\
\text { shopping }\end{array}$ & Both & No & No & $\begin{array}{l}\text { Drivers affecting satisfaction and } \\
\text { dissatisfaction are not equivalent, and } \\
\text { they have industry-specific differences. }\end{array}$ \\
\hline $\begin{array}{l}\text { Gummerus \& } \\
\text { Pihlström } \\
\text { (2011) }\end{array}$ & $\begin{array}{l}\text { Value perceptions } \\
\text { on mobile services }\end{array}$ & Positive & No & No & $\begin{array}{l}\text { Value comprises context value and in- } \\
\text { use value. }\end{array}$ \\
\hline $\begin{array}{l}\text { Salo et al. } \\
\qquad(2013)\end{array}$ & $\begin{array}{l}\text { Value perceptions } \\
\text { on mobile services }\end{array}$ & Positive & No & No & $\begin{array}{l}\text { The experiences reflect utilitarian self- } \\
\text { and other-oriented, as well as hedonic } \\
\text { self- and other-oriented, value types. }\end{array}$ \\
\hline Salo (2013) & $\begin{array}{l}\text { Dissatisfaction with } \\
\text { mobile services }\end{array}$ & Negative & No & No & $\begin{array}{l}\text { The sources for extreme negative } \\
\text { experiences can be external, internal, } \\
\text { and situational. }\end{array}$ \\
\hline $\begin{array}{l}\text { Meuter et al. } \\
\qquad(2000)\end{array}$ & $\begin{array}{l}\text { (Dis)satisfaction } \\
\text { with self-service } \\
\text { technologies }\end{array}$ & Both & Yes & No & $\begin{array}{l}\text { Different source categories for negative } \\
\text { incidents have different influences on } \\
\text { complaining and future behaviors. }\end{array}$ \\
\hline Serenko (2006) & $\begin{array}{l}\text { Description of } \\
\text { critical email agent } \\
\text { incidents }\end{array}$ & Both & Yes & No & $\begin{array}{l}\text { Context-specific findings on issues } \\
\text { affecting critical email agent incidents. }\end{array}$ \\
\hline $\begin{array}{l}\text { Serenko \& } \\
\text { Stach (2009) }\end{array}$ & $\begin{array}{l}\text { The influence of } \\
\text { critical online travel } \\
\text { service incidents on } \\
\text { word-of-mouth and } \\
\text { loyalty }\end{array}$ & Both & Yes & No & $\begin{array}{l}\text { Context-specific findings on issues } \\
\text { affecting critical online travel service } \\
\text { incidents. }\end{array}$ \\
\hline $\begin{array}{l}\text { Serenko \& } \\
\text { Turel (2010) }\end{array}$ & $\begin{array}{l}\text { Description of } \\
\text { critical email usage } \\
\text { incidents }\end{array}$ & Both & Yes & No & $\begin{array}{l}\text { Context-specific findings on issues } \\
\text { affecting critical email usage incidents. }\end{array}$ \\
\hline
\end{tabular}


During the fifties, psychologists started to pay attention to individuals' critical incidents related to their work behaviors (c.f. Flanagan 1954). However, it took a few decades for researchers to recognize that critical incidents are crucial also in the context of product and service usage: Gremler (2004) points out that particularly the study by Bitner, Booms and Tetreault (1990) launched a series of studies that examined customers' critical service incidents. This series of studies focused merely on critical incidents of traditional service usage in the fields of service research, marketing, and management.

The context of technology usage came to the picture a decade later, as Meuter et al. (2000) published their now widely known study regarding users' critical incidents of self-service technologies. They identified different sources for positive and negative incidents and found that different types of negative incidents may lead to different post-experience behaviors. Serenko and his fellow researchers (2006, 2009, 2010) were among the firsts to emphasize that also IS researchers should focus on critical incidents of IS usage. They presented context-specific findings about the sources of critical incidents related to usage of email (Serenko 2006; Serenko \& Turel 2010) and online travel services (Serenko \& Stach 2009). Their findings enabled them to report typical usage scenarios (Serenko 2006), post-experience behaviors (Serenko \& Stach 2009), and behavioral changes caused by the incidents (Serenko \& Turel 2010). For example, Serenko (2006) presented that if an email agent acts highly intrusively, the user most likely decides to permanently terminate usage. As one of the main conclusions, Serenko and Turel (2010, p. 196) state that "it is possible to identify incident causes that have the most dramatic impact on future user behavior".

Even though these studies offer a valuable first look at the link between critical incidents and user behaviors, importantly, all of them are missing the link between the situational context and users' postexperience behaviors (as illustrated in Table 1). By examining this missing link, it is possible to provide theoretical insights, identify the most crucial incidents, and offer practical implications for improving customer relationships.

\section{Studies on Situational Context}

With mobile use in general, situational context has been found to influence adoption and user behaviors (Liang \& Yeh 2010; Liu \& Li 2011; Mallat et al. 2008, 2009; van der Heijden, Ogertschnig \& van der Gast 2005; Wang \& Yi 2012; Yang et al. 2012). Prior studies have succeeded to provide interesting first insights but have been limited in measuring situational characteristics with only one abstract construct (e.g., Liu \& Li 2011; Mallat et al. 2008, 2009; Yang et al. 2012; Wang \& Yi 2012) or its effect on only one type of user behavior (e.g., Liang \& Yeh 2010; Xu \& Yuan 2009). Therefore, we attempt to extend this knowledge by understanding the uncovered relationships between specific situational characteristics and different types of post-experience behaviors. Venkatesh, Thong and $\mathrm{Xu}$ (2012, p. 158) have recently argued for the importance of such an approach in IS: "Compared to general theories, in more recent years, theories that focus on a specific context and identify relevant predictors and mechanisms are considered to be vital in providing a rich understanding of a focal phenomenon and to meaningfully extend theories." 
Related literature has identified certain influential characteristics of the situational context regarding consuming in general, as well as IS and mobile use. We focus on four situational characteristics reflecting dimensions that have been repeatedly specified in the mobile domain: interaction state as task definition (Belk 1975; Coursaris \& Kim 2011; Jumisko-Pyykkö \& Vainio 2010; Mallat et al. 2009), place as physical surroundings (Belk 1975; Coursaris \& Kim 2011; Jumisko-Pyykkö \& Vainio 2010; Lee, Kim \& Kim 2005; Mallat et al. 2009), level of sociality as social surroundings (Belk 1975; Coursaris \& Kim 2011; JumiskoPyykkö \& Vainio 2010; Lee, Kim \& Kim 2005; Mallat et al. 2009), and application type as technology (Coursaris \& Kim 2011; Hong \& Tam 2006; Jumisko-Pyykkö \& Vainio 2010; Venkatesh et al. 2011). In the selection of these four characteristics, we aimed to rule in and combine the most essential characteristics mentioned in the previous literature. Yet, we acknowledge that some situational characteristics had to be partly left out: for example, time perception, level of multitasking, culture, and antecedent emotional state as mentioned by Belk (1975), Jumisko-Pyykkö and Vainio (2010) and Lee, Kim and Kim (2005). Please see the article by Jumisko-Pyykkö and Vainio (2010) for a comprehensive list of potential contextual components in the mobile domain. However, we believe that the characteristics of our choice are among the most influential and the most beneficial to understand, especially from the perspective of application providers, since the providers assumedly have more possibilities to take these characteristics into account when designing mobile applications and instructing people on how to use them.

First, task or activity definition refers to the nature of the user's interaction with the technology (Belk 1975; Coursaris \& Kim 2011; Mallat et al. 2009). We apply Apter's (1989) reversal theory, which is one comprehensive way to capture IS users' interaction states, for two reasons: it has strengths in explaining "the dynamic aspects of human experience and behavior" (Deng \& Poole 2010, p. 715) and IS and human-computer interaction researchers have provided interesting insights with the reversal theory, but excluded its relationship with different types of user behaviors (Deng \& Poole 2010; Hassenzahl 2003; Hassenzahl, Kekez \& Burmester 2002). According to the reversal theory, each person operates with a product or a service either in a task-oriented or activity-oriented interaction state (Apter 1989). In the task-oriented interaction state, a person has some certain goal or task in mind, while in the activityoriented state the focus of the interaction lies with the activity itself in a more unconcerned way (Apter 1989; Deng \& Poole 2010; Hassenzahl 2003). In the task-oriented state, an individual prefers low arousal and orientates toward the future, while in the activity-oriented state, one prefers high arousal and focuses on the present time (Apter 1989; Deng \& Poole 2010).

Second, place has been mentioned as one of the unique characteristics, since mobile services can be used anywhere (Coursaris \& Kim 2011; Hong \& Tam 2006; Lee, Kim \& Kim 2005). Some recent studies examine the effect of place on mobile use. With mobile taxi services, Xu and Yuan (2009) have found that suburban location has a more positive impact on use intention than urban location. Liang and Yeh (2011) present that their respondents felt more playful when thinking about playing mobile games at home than at office or school. In order to categorize place, we apply the categorization by Lee, Kim and Kim (2005): users may employ mobile applications indoors, outdoors, and in a vehicle. Lee, Kim and Kim (2005) offer 
important information about the degree to which users apply mobile Internet in these different places, but do not provide any answers regarding the relationship between place and post-experience behaviors.

Third, the use situations of mobile applications relate to a certain level of sociality (Lee, Kim \& Kim 2005; Mallat et al. 2009). Co-experiences and shared experiences have gained growing attention in the mobile domain (Battarbee \& Koskinen 2005; Jacucci, Oulasvirta \& Salovaara 2007; Teevan et al. 2011), but such an approach seems to be unused in understanding different post-experience behaviors. Therefore, we compare two types of experiences by using the following distinction: mobile applications can be used alone or the use situation may involve other persons.

Fourth, contextual characteristics involve the technology artefact itself (Coursaris \& Kim 2011; Venkatesh et al. 2011). Within the mobile context, there are application types for numerous use purposes (Hong \& Tam 2006). As our article focuses on the situational context, we categorized the application types with regard to their interactivity with the context. At the most interactive level, physical mobile interactions (PMI) require a concrete, spatial interaction from the user with one's device: through PMI, users are able to form connections between mobile device and real-world surroundings or objects by touching (e.g., NFC), pointing (e.g., QR codes), scanning (e.g., Bluetooth), or using manual input (Rukzio et al. 2007). At the next level, location-based services (LBS) include applications that use the location information but do not require any concrete interaction. Finally, other applications do not usually require any interaction between the user and the context.

\section{Users' Post-experience Behaviors}

The extensively acknowledged potential behaviors after product or service experiences include use continuance (or repurchase), word-of-mouth communication, and complaints (Holloway \& Beatty 2008; Meuter et al. 2000; Serenko \& Stach 2009; Zeithaml, Berry \& Parasuraman 1996; Zhou 2011). In IS context, use continuance denotes whether or not the user continues to use the IS artifact in question after the initial adoption (Bhattacherjee 2001). Positive/negative word-of-mouth refers to saying positive/negative things and sharing positive/negative information or recommendations about a product or service to other person(s) (Serenko \& Stach 2009; Zeithaml, Berry \& Parasuraman 1996). In this study, complaints refer to behavior in which the user initiatively complains about a negative experience to the product or service provider (Bougie, Pieters \& Zeelenberg 2003).

From the perspective of the product or service provider, use continuance and positive word-of-mouth are categorized as favorable behaviors, while use discontinuance, negative word-of-mouth, and complaints are referenced as unfavorable behaviors (Zeithaml, Berry \& Parasuraman 1996). The importance of postexperience behaviors for service providers is self-evident, since such favorable and unfavorable behaviors have direct effects on maintaining old customer relationships as well as acquiring new customers. Still, post-experience behaviors have been highlighted even more in the context of electronic and mobile services, because the lack of social interaction with staff can lead to higher a negative affect and use 
discontinuance, whereas, word-of-mouth and complaints can spread quickly with the help of mobile networks, user-generated content, and social features (Chea \& Luo 2008; Zhou 2011).

\section{Conceptual Model}

By following a set of previous studies (Liang \& Yeh 2010; Liu \& Li 2011; Mallat et al. 2008, 2009; van der Heijden, Ogertschnig \& van der Gast 2005; Wang \& Yi 2012; Yang et al. 2012), our conceptual model depicts that the situational context has a relationship with user behaviors. As illustrated in Figure 1, we specify the previous more abstract models by focusing on the presented four situational characteristics (interaction state, place, sociality, and application type) and the three types of post-experience behaviors (use continuance, word-of-mouth, and complaints). ${ }^{1}$ In sum, we aim to uncover and explain the relationships between the situational characteristics and post-experience behaviors with the help of empirical evidence.

Situational

context

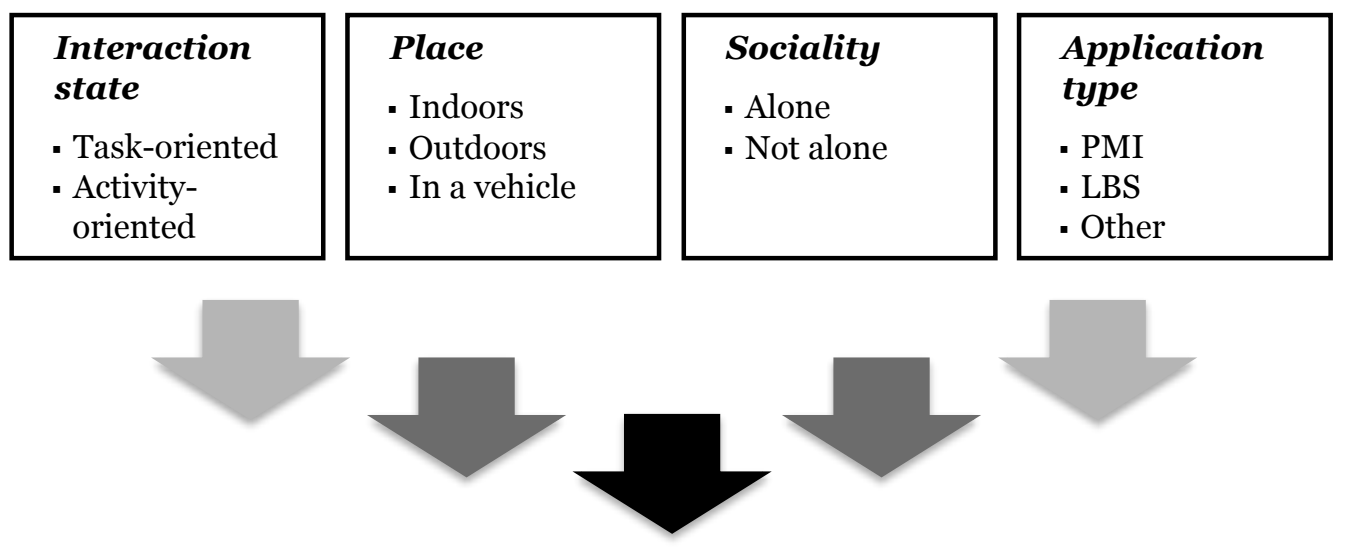

Post-Experience

Behaviors

- Use continuance

- Word-of-mouth

- Complaints

Figure 1. The Conceptual Model: The Relationship of Situational Context with Post-Experience Behaviors.

${ }^{1}$ Even though this article focuses on the relationship between situational context and post-experience behaviors, please note that also other aspects such as perceived value (Yang et al. 2012) may influence post-experience behaviors. 


\section{Method}

\section{Critical Incident Technique}

The critical incident technique (CIT) fits our purpose of collecting actual experiences from mobile application users since the well-established technique enables asking respondents to describe their positive and negative critical incidents with products and services. Along with self-reported narratives of incidents, CIT questionnaires can include questions concerning users' post-experience behaviors (cf., Meuter et al. 2000). In summary, CIT "consists of a set of procedures" (Flanagan 1954, p. 327) "to collect, content analyze, and classify observations of human behavior" (Gremler 2004, p. 66; Grove \& Fisk 1997, p. 67).

Methodologically, there are three relevant advantages of CIT. First, researchers are able to gain a thorough understanding of undiscovered phenomena (Gremler 2004; Meuter et al. 2000), such as user behaviors after critical mobile incidents. Second, respondents only report the incidents that are particularly relevant and important for them. Third, critical incidents are easy to remember and describe. Nonetheless, there are also some weaknesses related to CIT (Bitner, Booms \& Tetreault 1990; Gremler 2004). First, CIT only captures the extremes of positive and negative incidents without paying attention to regular incidents. However, in this study, we specifically wanted to focus on such extreme incidents. Second, there is a risk for recall bias. To address this risk, we encouraged participants to pace themselves, take a few moments to properly recall the incident, and describe it in as much detail as possible.

\section{Study Design, Data Collection, and Measurement}

We followed relevant guidelines for CIT studies presented by Gremler (2004). We carried out an iteratively designed online questionnaire with a pre-test and a pilot phase. In the pre-test, six persons (including both potential respondents and fellow researchers) provided comments about the questionnaire. In the pilot phase, 22 respondents completed the questionnaire. After final improvements, we distributed the questionnaire to Finnish mobile application users during the summer of 2012 via online forums related to news, sports, hobbies, parenting, family, women's magazines, seniors, technology, gaming, business, science, and agriculture. With this multi-forum targeting approach, we aimed to collect a representative sample that would resemble the Finnish mobile Internet users and reach a wide audience with different backgrounds regarding age, gender, education, profession, and lifestyle. To motivate the respondents, we announced that one gift card worth 150 euros and ten smaller prizes would be raffled off and awarded.

A set of widely cited CIT-related articles (e.g., Bitner, Booms \& Tetreault 1990; Johnston 1995; Meuter et al. 2000) encouraged us to use an exact wording when asking the respondents to "think of a time when you had an outstandingly positive or negative experience with a mobile application" ${ }^{2}$. After the

\footnotetext{
${ }^{2}$ The language of the questionnaire was Finnish.
} 
respondents chose to report either a positive or a negative incident and had named the associated mobile application, they described the incident in their own words by answering several open-ended questions. In terms of situational characteristics, the respondents answered structured questions about in which surrounding environment (indoors, outdoors or in a vehicle) and in what kind of social setting the incident occurred (alone or not alone).

To overcome the typical limitation of collecting only behavioral intentions, we measured both intended and actual post-experience behaviors. For intended behaviors, we asked each respondent to indicate agreement with randomized statements concerning consequences of their freshly described incident-use continuance, word-of-mouth, and complaints-on a 5-point Likert scale (from 1 = "strongly disagree" to 5 = "strongly agree"). There was also an option for "no answer" to reduce the likelihood of forced responses. We measured each of the constructs by adapting and modifying three statements per construct from validated instruments presented in prior studies. The statements, reference studies, and associated Cronbach's alphas are presented in Table 2. The values of Cronbach's alpha exceed the suggested minimum for exploratory research (0.7) for each construct (Nunnally \& Bernstein 1994), so the constructs can be considered reliable and internally consistent. For actual behaviors, the respondents answered structured "yes or no" questions regarding use continuance, word-of-mouth, and complaints (Table 3).

Table 2. Intended Behaviors: Items by Constructs, Reference Studies, and Associated Cronbach's Alphas

As a consequence of the experience I just described, I wanted to...

Use continuance, $\boldsymbol{\alpha}=\mathbf{0 . 9 1 0}$ (adapted from Bhattacherjee 2001; Mathieson 1991)

... continue using the application in the future rather than discontinue its use.

... discontinue my use of the application. (reverse coded)

... continue using the application in the future.

Positive word-of-mouth, $\boldsymbol{\alpha}=\mathbf{0 . 9 0 5}$ (adapted from Zeithaml, Berry \& Parasuraman 1996)

(only shown for respondents who chose to describe positive experiences)

... encourage my friends to use the application.

... say positive things about the application to other people.

... recommend the application to other people.

Negative word-of-mouth, $\boldsymbol{\alpha}=\mathbf{0 . 8 0 5}$ (adapted from Lang 2009; Zeithaml, Berry \& Parasuraman 1996)

(only shown for respondents who chose to describe negative experiences)

... advise my friends not to use the application.

... say negative things about the application to other people.

... suggest to other people that they avoid the use of the application.

Complaints, $\alpha=\mathbf{0 . 8 6 3}$ (adapted from Bougie, Pieters \& Zeelenberg 2003; Chea \& Luo 2008; Zhou 2011)

(only shown for respondents who chose to describe negative experiences)

... let the application provider know about my experience.

... give feedback to the application provider about my experience.

... complain about my experience. 


\section{Table 3. Actual Behaviors: Items and Reference Studies}

Use continuance (modified from Serenko \& Stach 2009)

Have you entirely quitted using the app because of the experience?

Word-of-mouth (modified from Serenko \& Stach 2009)

Have you told about your experience to others?

Complaints (modified from Meuter et al. 2000)

(only shown for respondents who chose to describe negative experiences)

Have you made a complaint about the experience?

\section{Analysis}

In order to ensure the quality of the empirical evidence, criteria for including and excluding respondents' critical incidents needed to be defined (Bitner, Booms \& Tetreault 1990; Gremler 2004; Sweeney \& Lapp 2004). To be considered valid for this study, a response was required that related to a single outstandingly positive or negative incident that involved a specific mobile application. The response was also required to have a sufficient description and include at least one answer to questions concerning post-experience behaviors. Among the 619 responses, 605 met these criteria and were included as units of analysis.

In the responses, each user specifically stated whether the incident was positive or negative and reported the place, the level of sociality, and the application in question. To determine which interaction state (as defined in the section entitled Studies on Situational Context) to which each incident related, we qualitatively analyzed each respondent's incident description and coded incidents including a clear goal or task as being task-oriented and other incidents as activity-oriented. As we wanted to measure interrater reliability for such strict codings, another independent analyst, blind to the initial codings, coded 70 incident descriptions. The values for percent-agreement figure (91.4\%) and Cohen's Kappa (0.82) indicate that the level of agreement is sufficient.

We used statistical analysis software (SPSS, release 19.0.0) in order to find out whether there are statistically significant differences related to the situational characteristics and post-experience behaviors. Regarding intended behaviors, we calculated mathematical means of the items for each construct. For variables with only two nominal categories, we used a $t$-test. Similarly for variables including three nominal categories, we used analysis of variance (ANOVA) tests. With ANOVA, we used Tukey's and Tamhane's T2 as post-hoc tests for pair comparisons. For actual behaviors that were measured with nominal scales, we used crosstabs. For tables larger than 2x2, we examined Pearson's chi-square or Fisher's exact test. For 2x2 tables, we investigated Yates's Continuity Correction.

After the statistical analyses, we sought to identify explanatory tendencies for the statistically significant relationships. Thus, we conducted a qualitative content analysis on the open-ended incident descriptions by following the applicable guidelines for content analytic CIT studies set by Gremler (2004) and general 
instructions for qualitative approaches by Sarker, Xiao \& Beaulieu (2012). We used the results of the statistical analyses in reducing the evidence and defining what is important: the focus was placed on the characteristics of the incidents after which users more likely engaged positive or negative behaviors. More specifically, our analysis followed the following four steps suggested by Gremler (2004):

Step 1. One author read and reread the evidence carefully in order to find common and explanatory tendencies for each statistically significant relationship. The initial insights were discussed with other scholars.

Step 2. By paying attention to the tendencies in the respondents' descriptions, the author identified keywords and recurring themes regarding each statistically significant relationship.

Step 3. Based on the recurring themes, the author developed a categorization scheme and discussed it with other scholars.

Step 4. Finally, we formed a description for each category.

However, we did not conduct any explicit coding because we searched the evidence for main tendencies rather than the distribution or the whole variety of different explanations. Sarker, Xiao \& Beaulieu (2012) confirm that not all qualitative approaches require explicit coding. To make our analysis more transparent, we present our category descriptions with examples in the Appendix B, as suggested by Sarker, Xiao \& Beaulieu (2012).

\section{Respondents}

Regarding age, gender, and education distribution, the group of respondents is fairly similar to the target population of Finnish mobile Internet users (Table 4, cf., Statistics Finland 2012) and, thus, is well in line with the purpose of this study. The ages vary from 7 to 95 years with a mean age of 33.3 years. In terms of education, the group of respondents is diverse, even though higher degrees are rather common among the respondents. As expected for mobile Internet users, the respondents agreed rather highly with statements concerning IS use, mobile usage skills, and personal innovativeness. 


\begin{tabular}{|l|c|c|c|}
\hline \multicolumn{3}{|c|}{ Table 4. Respondents' Characteristics (n = 605) } \\
\hline & Frequency & Percentage & $\begin{array}{c}\text { Target } \\
\text { population, } \\
\text { percentage }\end{array}$ \\
\hline Gender & & & \\
Male & 419 & $69.3 \%$ & $67.3 \%$ \\
Female & 186 & $30.7 \%$ & $32.7 \%$ \\
\hline Age & & & \\
$16-24$ & 140 & $23.7 \%$ & $20.2 \%$ \\
$25-34$ & 198 & $33.5 \%$ & $26.7 \%$ \\
$35-44$ & 150 & $25.4 \%$ & $26.3 \%$ \\
$45-54$ & 70 & $11.8 \%$ & $16.5 \%$ \\
$55-64$ & 27 & $4.6 \%$ & $8.6 \%$ \\
$65-74$ & 6 & $1.0 \%$ & $2.3 \%$ \\
\hline Education & & & \\
Comprehensive school or equivalent & 53 & $8.8 \%$ & N/A \\
Upper secondary education or equivalent & 286 & $47.3 \%$ & N/A \\
Bachelor's degree or equivalent & 136 & $22.5 \%$ & N/A \\
Master's degree or equivalent and higher & 127 & $21.0 \%$ & N/A \\
\hline
\end{tabular}

\section{Results}

In total, the respondents reported 516 (85\%) positive and 89 (15\%) negative critical incidents that were included in the analysis. Each respondent also rated how much (dis)satisfaction the incident caused on a 5 -point scale ( $1=$ "not at all" to 5 = "extremely much"). The mean rating was 4.14 for positive and 3.65 for negative incidents. The incidents were affiliated with numerous applications: the most frequent PMI applications involved visual code scanning (28\% of all incidents), music recognition (18\%), and image recognition (7\%); LBS applications involved location information, navigation, and sharing (12\%) and sports tracking (9\%); other applications involved social networking (9\%) and Web browsing (5\%).

Figure 2 summarizes our findings and presents the resulting model for the relationship between the specific situational context and post-experience behaviors. The nature of the relationship and its explanatory characteristics regarding each finding (F) are presented more thoroughly in the following subsections. 


$\begin{array}{cccc}\begin{array}{c}\text { Situational } \\ \text { context }\end{array} & \text { The nature of the relationship } & \begin{array}{c}\text { Explanatory } \\ \text { characteristics }\end{array} & \begin{array}{c}\text { Post-Experience } \\ \text { Behaviors }\end{array}\end{array}$

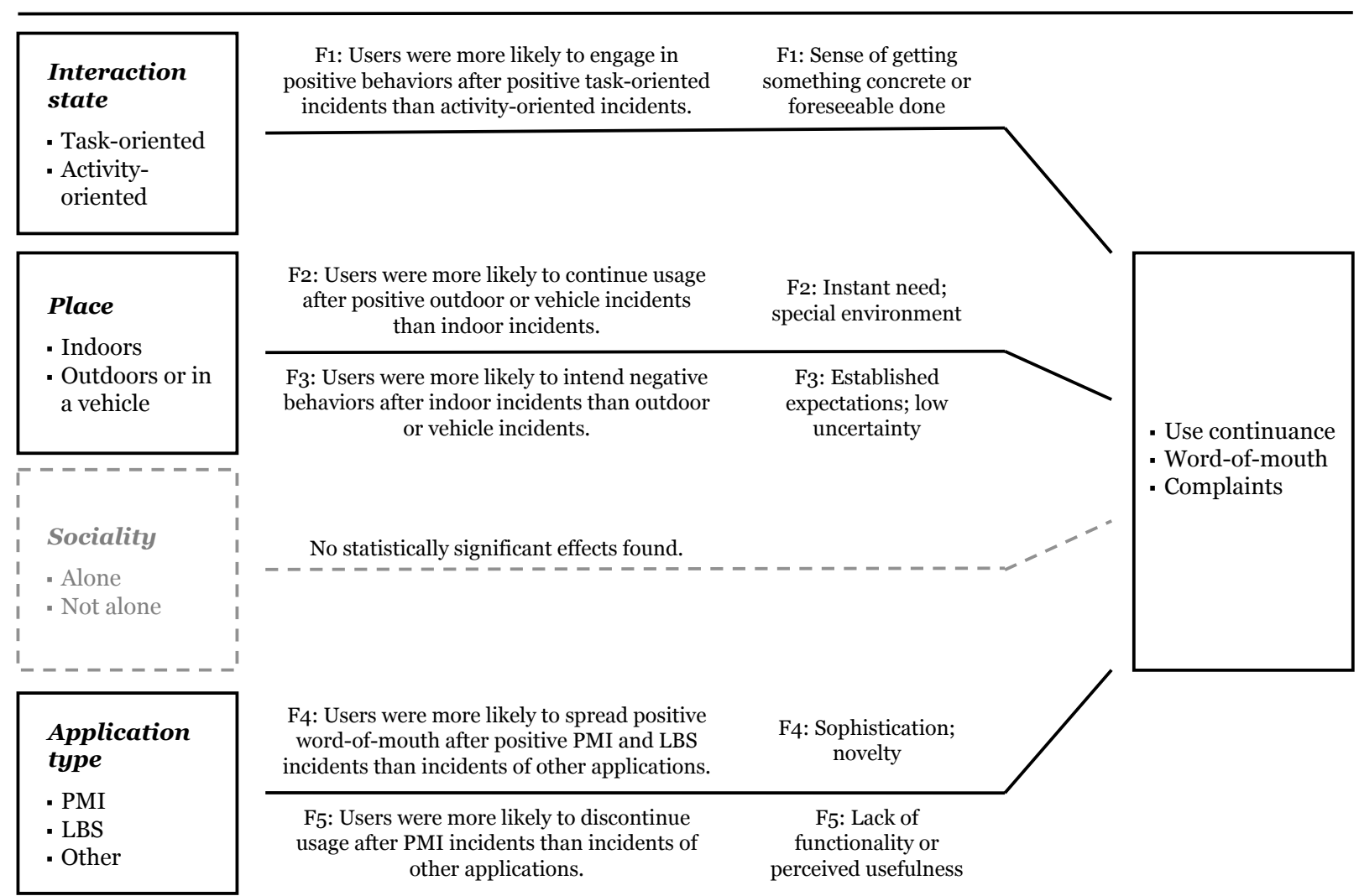

Figure 2. The Resulting Research Model: The Relationship of Situational Context with Post-Experience Behaviors. 


\section{Interaction state}

Within positive incidents (Table 5), there was a statistically significant difference for interaction state across all measured constructs: task-oriented incidents reflected higher intended and actual use continuance and positive word-of-mouth (F1). Nearly all users (98\%) had continued the use of the application after incidents that included a clear task or goal and a great majority (71\%) had also told other people about such positive incidents.

Regarding F1, we found distinctive characteristics between task-oriented and activity-oriented incidents in the content analysis of the written incident descriptions. Many users described task-oriented incidents as getting something concrete, practical, and foreseeable done. In these cases, users already had a specific need, often recurrent in ordinary life, in mind before using the application ("I had to pay bills;" "I purchased a ticket"). In contrast, with activity-oriented incidents the users tended to use the application unexpectedly without a prior plan ("A [2D code] on a coffee bag persuaded me to check what the code would uncover"). It appeared to us that, because of the practicality and predictability, task-oriented incidents provide a steady foundation for positive post-experience behaviors.

In the case of negative incidents (Table 6), there were no statistically significant differences for interaction state.

\begin{tabular}{|c|c|c|c|c|c|c|}
\hline \multicolumn{7}{|c|}{ Table 5. Interaction State and Positive Incidents } \\
\hline & \multicolumn{2}{|c|}{$\begin{array}{l}\text { Intended Behaviors } \\
\text { (Construct mean) }\end{array}$} & \multicolumn{4}{|c|}{$\begin{array}{c}\text { Actual Behaviors } \\
\text { (\% and N of respondents) }\end{array}$} \\
\hline & $\begin{array}{c}\text { Use } \\
\text { continuance } \\
* * *\end{array}$ & $\begin{array}{l}\text { Positive } \\
\text { word-of- } \\
\text { mouth ** }\end{array}$ & \multicolumn{2}{|c|}{$\begin{array}{l}\text { Entirely quit using } \\
\text { the app after the } \\
\text { experience }\end{array}$} & \multicolumn{2}{|c|}{$\begin{array}{l}\text { Told others about } \\
\text { the experience }\end{array}$} \\
\hline $\begin{array}{l}\text { Task- } \\
\text { oriented }\end{array}$ & 4.68 & 4.20 & $\begin{array}{c}1.6 \% \\
(5)\end{array}$ & $\begin{array}{l}98.4 \% \\
(300)\end{array}$ & $\begin{array}{r}71.2 \% \\
(208)\end{array}$ & $\begin{array}{c}28.8 \% \\
(84)\end{array}$ \\
\hline $\begin{array}{l}\text { Activity- } \\
\text { oriented }\end{array}$ & 4.39 & 4.00 & $\begin{array}{c}13.6 \% \\
(28)\end{array}$ & $\begin{array}{c}86.4 \% \\
(178)\end{array}$ & $\begin{array}{r}54.2 \% \\
(110)\end{array}$ & $\begin{array}{c}45.8 \% \\
(93)\end{array}$ \\
\hline Test result & $\begin{array}{c}t(401)=4.60, \\
N=511, \\
p=0.000\end{array}$ & $\begin{array}{c}t(509)=2.64, \\
N=511, \\
p=0.009\end{array}$ & $\begin{array}{l}X^{2} \text { Yates } \\
=27.14\end{array}$ & $\begin{array}{l}N=511) \\
=0.000\end{array}$ & $\begin{array}{l}X^{2} \text { Yates } \\
=14.4\end{array}$ & $\begin{array}{l}N=495) \\
=0.000\end{array}$ \\
\hline
\end{tabular}




\begin{tabular}{|c|c|c|c|c|c|c|c|c|c|}
\hline \multicolumn{10}{|c|}{ Table 6. Interaction State and Negative Incidents } \\
\hline & \multicolumn{3}{|c|}{$\begin{array}{l}\text { Intended Behaviors } \\
\text { (Construct mean) }\end{array}$} & \multicolumn{6}{|c|}{$\begin{array}{c}\text { Actual Behaviors } \\
\text { (\% and } N \text { of respondents) }\end{array}$} \\
\hline & \multirow[t]{2}{*}{$\begin{array}{l}\text { Use } \\
\text { continuance }\end{array}$} & \multirow[t]{2}{*}{$\begin{array}{l}\text { Negative } \\
\text { word-of- } \\
\text { mouth }\end{array}$} & \multirow[t]{2}{*}{ Complaints } & \multicolumn{2}{|c|}{$\begin{array}{l}\text { Entirely quit using } \\
\text { the app because of } \\
\text { the experience }\end{array}$} & \multicolumn{2}{|c|}{$\begin{array}{l}\text { Told others about } \\
\text { the experience }\end{array}$} & \multicolumn{2}{|c|}{$\begin{array}{c}\text { Made a complaint } \\
\text { about the } \\
\text { experience }\end{array}$} \\
\hline & & & & Yes & No & Yes & No & Yes & No \\
\hline $\begin{array}{l}\text { Task- } \\
\text { oriented }\end{array}$ & 2.63 & 2.87 & 2.51 & $\begin{array}{c}47.9 \% \\
(23)\end{array}$ & $\begin{array}{c}52.1 \% \\
(25)\end{array}$ & $\begin{array}{c}53.2 \% \\
(25)\end{array}$ & $\begin{array}{c}46.8 \% \\
(22)\end{array}$ & $\begin{array}{c}4.2 \% \\
(2)\end{array}$ & $\begin{array}{c}95.8 \% \\
(46)\end{array}$ \\
\hline $\begin{array}{l}\text { Activity- } \\
\text { oriented }\end{array}$ & 2.28 & 2.91 & 2.48 & $\begin{array}{c}61.5 \% \\
(24)\end{array}$ & $\begin{array}{c}38.5 \% \\
(15)\end{array}$ & $\begin{array}{c}47.4 \% \\
(18)\end{array}$ & $\begin{array}{c}52.6 \% \\
(20)\end{array}$ & $\begin{array}{c}7.7 \% \\
(3)\end{array}$ & $\begin{array}{c}92.3 \% \\
(36)\end{array}$ \\
\hline Test result & $\begin{array}{c}t(82)=1.42 \\
N=84 \\
p=0.158\end{array}$ & $\begin{array}{c}t(84)=-0.16, \\
N=86 \\
p=0.870\end{array}$ & $\begin{array}{c}t(81)=0.096, \\
N=83, \\
p=0.924\end{array}$ & $\begin{array}{l}X^{2} \text { Yates } \\
=1.11\end{array}$ & $\begin{array}{l}N=87) \\
=0.293\end{array}$ & $\begin{array}{l}X^{2} \text { Yate } \\
=0.10\end{array}$ & $\begin{array}{l}N=85) \\
0.752\end{array}$ & $\begin{array}{r}\text { Fis } \\
(N=87\end{array}$ & $\begin{array}{l}\text { test } \\
=0.653\end{array}$ \\
\hline
\end{tabular}

\section{Place}

After positive incidents (Table 7) that took place outdoors or in a vehicle, users were more likely to continue the usage of the application (F2). The difference for place was statistically significant with both intended and actual use continuance. For positive word-of-mouth, there was no difference for place.

Related to F2, users described instant needs or desires preceding outdoor and vehicle incidents ("I had to find a restaurant quickly from a nearby site.”) In these special environments, users often had no other alternative options ("[The mobile application] was the only option"). With some of the outdoor and vehicle incidents, users highlighted the appreciation of the functionality in demanding environment ("I was surprised that I could use [the application] wherever. ... [I was] on a bus.”) When successful, it seemed that incidents involving an instant need or a special place impressed users and encouraged them to engage in positive behaviors.

With negative incidents (Table 8), users were more likely to intend to engage in negative word-of-mouth and complain about the incident when the incident took place indoors than outdoors or in a vehicle (F3). Indeed, all actual complaints were about indoor incidents. However with actual negative word-of-mouth, there was no difference for place.

With F3, many indoor incidents took place in familiar environments (e.g., at home or office). These environments often reflected high expectations and low uncertainty: users expected the incidents to proceed faultlessly since they were accustomed to the fact that the applications would work as they usually did ("I used the application normally but it didn’t work"). Failures in such occasions caused particular disappointment. Instead, when using the applications outdoors or in a vehicle, users often had doubts in 
advance of whether or not the application would function ("I wanted to try to find out whether I could get along with a mobile phone [outside during a run];" "I would like to use the mobile app [outside], but it rarely works."). Based on the analysis, we consider the established expectations and low uncertainty of indoor incidents as the main reasons why users more likely had negative behavioral intentions after negative indoor incidents.

Originally, we categorized incidents into groups labeled "indoors," "outdoors," and "in a vehicle," but we needed to combine the groups "outdoors" and "in a vehicle" to be able to run statistical tests. With an additional inspection of incidents that happened in vehicles, we found that users were less likely to quit (intended use continuance 2.85, $\mathrm{N}=9$; actual quits: $44.4 \%, \mathrm{~N}=9$ ) and complain (intended complaints 1.48, $\mathrm{N}=9$; actual complaints: $0.0 \%, \mathrm{~N}=9$ ) after negative incidents that occurred in vehicles than elsewhere. Correspondingly, with positive incidents that took place in vehicles, users had the highest intentions for use continuance (4.69, N=78) and positive word-of-mouth (4.25, N=78).

\begin{tabular}{|c|c|c|c|c|c|c|}
\hline \multicolumn{7}{|c|}{ Table 7. Place and Positive Incidents } \\
\hline & \multicolumn{2}{|c|}{$\begin{array}{l}\text { Intended Behaviors } \\
\text { (Construct mean) }\end{array}$} & \multicolumn{4}{|c|}{$\begin{array}{c}\text { Actual Behaviors } \\
\text { (\% and } N \text { of respondents) }\end{array}$} \\
\hline & \multirow[t]{2}{*}{$\begin{array}{c}\text { Use } \\
\text { continuance } \\
* *\end{array}$} & \multirow[t]{2}{*}{$\begin{array}{l}\text { Positive } \\
\text { word-of- } \\
\text { mouth }\end{array}$} & \multicolumn{2}{|c|}{$\begin{array}{l}\text { Entirely quit using } \\
\text { the app after the } \\
\text { experience * }\end{array}$} & \multicolumn{2}{|c|}{$\begin{array}{l}\text { Told others about } \\
\text { the experience }\end{array}$} \\
\hline & & & Yes & No & Yes & No \\
\hline Indoors & 4.48 & 4.07 & $\begin{array}{c}8.4 \% \\
(25)\end{array}$ & $\begin{array}{c}91.6 \% \\
(271)\end{array}$ & $\begin{array}{c}64.4 \% \\
(186)\end{array}$ & $\begin{array}{c}35.6 \% \\
(103)\end{array}$ \\
\hline $\begin{array}{l}\text { Outdoors or } \\
\text { in a vehicle }\end{array}$ & 4.66 & 4.16 & $\begin{array}{c}3.7 \% \\
(8)\end{array}$ & $\begin{array}{c}96.3 \% \\
(208)\end{array}$ & $\begin{array}{l}62.8 \% \\
(130)\end{array}$ & $\begin{array}{c}37.2 \% \\
(77)\end{array}$ \\
\hline Test result & $\begin{array}{c}t(510)=-2.99 \\
N=512, \\
p=0.003\end{array}$ & $\begin{array}{c}t(510)=-1.22 \\
N=512, \\
p=0.224\end{array}$ & $\begin{array}{l}X^{2} \text { Yates } \\
=3.90\end{array}$ & $\begin{array}{l}V=512) \\
0.048\end{array}$ & $\begin{array}{l}X^{2} \text { Yates } \\
=0.07\end{array}$ & $\begin{array}{l}V=496) \\
0.794\end{array}$ \\
\hline
\end{tabular}




\begin{tabular}{|c|c|c|c|c|c|c|c|c|c|}
\hline \multicolumn{10}{|c|}{ Table 8. Place and Negative Incidents } \\
\hline & \multicolumn{3}{|c|}{$\begin{array}{l}\text { Intended Behaviors } \\
\text { (Construct mean) }\end{array}$} & \multicolumn{6}{|c|}{$\begin{array}{c}\text { Actual Behaviors } \\
\text { (\% and } N \text { of respondents) }\end{array}$} \\
\hline & \multirow[t]{2}{*}{$\begin{array}{c}\text { Use } \\
\text { continuance }\end{array}$} & \multirow[t]{2}{*}{$\begin{array}{l}\text { Negative } \\
\text { word-of- } \\
\text { mouth * }\end{array}$} & \multirow[t]{2}{*}{ Complaints * } & \multicolumn{2}{|c|}{$\begin{array}{l}\text { Entirely quit using } \\
\text { the app because of } \\
\text { the experience }\end{array}$} & \multicolumn{2}{|c|}{$\begin{array}{l}\text { Told others about } \\
\text { the experience }\end{array}$} & \multicolumn{2}{|c|}{$\begin{array}{c}\text { Made a complaint } \\
\text { about the } \\
\text { experience }\end{array}$} \\
\hline & & & & Yes & No & Yes & No & Yes & No \\
\hline Indoors & 2.33 & 3.06 & 2.70 & $\begin{array}{c}33 \\
(56.9 \%)\end{array}$ & $\begin{array}{c}25 \\
(43.1 \%)\end{array}$ & $\begin{array}{c}29 \\
(50.9 \%)\end{array}$ & $\begin{array}{c}28 \\
(49.1 \%)\end{array}$ & $\begin{array}{c}5 \\
(8.6 \%)\end{array}$ & $\begin{array}{c}53 \\
(91.4 \%)\end{array}$ \\
\hline $\begin{array}{l}\text { Outdoors or } \\
\text { in a vehicle }\end{array}$ & 2.73 & 2.54 & 2.06 & $\begin{array}{c}14 \\
(50 . \%)\end{array}$ & $\begin{array}{c}14 \\
(50.0 \%)\end{array}$ & $\begin{array}{c}14 \\
(50.0 \%)\end{array}$ & $\begin{array}{c}14 \\
(50.0 \%)\end{array}$ & $\begin{array}{c}0 \\
(0.0 \%)\end{array}$ & $\begin{array}{c}28 \\
(100 \%)\end{array}$ \\
\hline Test result & $\begin{array}{c}t(81)=-1.53 \\
N=83 \\
p=0.129\end{array}$ & $\begin{array}{c}t(83)=2.18 \\
N=85 \\
p=0.032\end{array}$ & $\begin{array}{c}t(80)=2.41 \\
N=82 \\
p=0.018\end{array}$ & $\begin{array}{l}X^{2} \text { Yates }( \\
=0.14,\end{array}$ & $\begin{array}{l}N=86) \\
=0.711\end{array}$ & $\begin{array}{l}X^{2} \text { Yates }( \\
=0.00\end{array}$ & $\begin{array}{l}N=85) \\
=1.000\end{array}$ & $\begin{array}{r}\text { Fish } \\
(N=86\end{array}$ & $\begin{array}{l}\text { s test } \\
p=0.168\end{array}$ \\
\hline
\end{tabular}

\section{Sociality}

Neither for positive (Table 9) nor negative incidents (Table 10) were there statistically significant differences for the level of sociality. However, we find it reasonable to report that users more likely intended and actually quit using the application in question after having negative incidents that were encountered alone: $63 \%$ of the respondents had quit using the application after such cases, while the corresponding percentage for other negative incidents was 44. Also, most of the actual complaints were related to incidents that the users underwent alone.

\begin{tabular}{|c|c|c|c|c|c|c|}
\hline \multicolumn{7}{|c|}{ Table 9. Sociality and Positive Incidents } \\
\hline & \multicolumn{2}{|c|}{$\begin{array}{l}\text { Intended Behaviors } \\
\text { (Construct mean) }\end{array}$} & \multicolumn{4}{|c|}{$\begin{array}{c}\text { Actual Behaviors } \\
\text { (\% and } N \text { of respondents) }\end{array}$} \\
\hline & \multirow[t]{2}{*}{$\begin{array}{c}\text { Use } \\
\text { continuance }\end{array}$} & \multirow[t]{2}{*}{$\begin{array}{c}\text { Positive } \\
\text { word-of- } \\
\text { mouth }\end{array}$} & \multicolumn{2}{|c|}{$\begin{array}{l}\text { Entirely quit using } \\
\text { the app after the } \\
\text { experience }\end{array}$} & \multicolumn{2}{|c|}{$\begin{array}{l}\text { Told others about } \\
\text { the experience }\end{array}$} \\
\hline & & & Yes & No & Yes & No \\
\hline Alone & 4.56 & 4.10 & $\begin{array}{l}4.4 \% \\
(10)\end{array}$ & $\begin{array}{c}95.6 \% \\
(215)\end{array}$ & $\begin{array}{l}62.6 \% \\
(137)\end{array}$ & $\begin{array}{c}37.4 \% \\
(82)\end{array}$ \\
\hline Not alone & 4.56 & 4.13 & $\begin{array}{l}7.6 \% \\
(22)\end{array}$ & $\begin{array}{l}92.4 \% \\
(268)\end{array}$ & $\begin{array}{l}65.0 \% \\
(182)\end{array}$ & $\begin{array}{c}35.0 \% \\
(98)\end{array}$ \\
\hline Test result & $\begin{array}{c}t(513)=0.07, \\
N=515, \\
p=0.948\end{array}$ & $\begin{array}{c}t(513)=-0.41 \\
N=515 \\
p=0.682\end{array}$ & $\begin{array}{r}X^{2} \text { Yates } \\
=1.6\end{array}$ & $\begin{array}{l}N=515) \\
=0.200\end{array}$ & $\begin{array}{l}X^{2} \text { Yates } \\
=0.22\end{array}$ & $\begin{array}{l}V=499) \\
=0.638\end{array}$ \\
\hline
\end{tabular}




\begin{tabular}{|c|c|c|c|c|c|c|c|c|c|}
\hline \multicolumn{10}{|c|}{ Table 10. Sociality and Negative Incidents } \\
\hline & \multicolumn{3}{|c|}{$\begin{array}{l}\text { Intended Behaviors } \\
\text { (Construct mean) }\end{array}$} & \multicolumn{6}{|c|}{$\begin{array}{c}\text { Actual Behaviors } \\
\text { (\% and } N \text { of respondents) }\end{array}$} \\
\hline & \multirow[t]{2}{*}{$\begin{array}{l}\text { Use } \\
\text { continuance }\end{array}$} & \multirow[t]{2}{*}{$\begin{array}{l}\text { Negative } \\
\text { word-of- } \\
\text { mouth }\end{array}$} & \multirow[t]{2}{*}{ Complaints } & \multicolumn{2}{|c|}{$\begin{array}{l}\text { Entirely quit using } \\
\text { the app because of } \\
\text { the experience }\end{array}$} & \multicolumn{2}{|c|}{$\begin{array}{l}\text { Told others about } \\
\text { the experience }\end{array}$} & \multicolumn{2}{|c|}{$\begin{array}{c}\text { Made a complaint } \\
\text { about the } \\
\text { experience }\end{array}$} \\
\hline & & & & Yes & No & Yes & No & Yes & No \\
\hline Alone & 2.33 & 2.90 & 2.51 & $\begin{array}{c}64.3 \% \\
(27)\end{array}$ & $\begin{array}{c}35.7 \% \\
(15)\end{array}$ & $\begin{array}{c}43.9 \% \\
(18)\end{array}$ & $\begin{array}{c}56.1 \% \\
(23)\end{array}$ & $\begin{array}{c}9.5 \% \\
(4)\end{array}$ & $\begin{array}{c}90.5 \% \\
(38)\end{array}$ \\
\hline Not alone & 2.61 & 2.88 & 2.48 & $\begin{array}{c}44.4 \% \\
(20)\end{array}$ & $\begin{array}{c}55.6 \% \\
(25)\end{array}$ & $\begin{array}{c}56.8 \% \\
(25)\end{array}$ & $\begin{array}{c}43.2 \% \\
(19)\end{array}$ & $\begin{array}{l}2.2 \% \\
(1)\end{array}$ & $\begin{array}{c}97.8 \% \\
(44)\end{array}$ \\
\hline Test result & $\begin{array}{c}t(82)=-1.14, \\
N=84, \\
p=0.257\end{array}$ & $\begin{array}{c}t(84)=0.11 \\
N=86 \\
p=0.915\end{array}$ & $\begin{array}{c}t(81)=0.09 \\
N=83 \\
p=0.927\end{array}$ & $\begin{array}{l}X^{2} \text { Yates } \\
=2.69,\end{array}$ & $\begin{array}{l}N=87) \\
0.101\end{array}$ & $\begin{array}{l}X^{2} \text { Yates } \\
=0.95\end{array}$ & $\begin{array}{l}N=85) \\
0.331\end{array}$ & $\begin{array}{r}\text { Fish } \\
(N=87\end{array}$ & $\begin{array}{l}\text { test } \\
=0.192\end{array}$ \\
\hline
\end{tabular}

\section{Application type}

With positive incidents (Table 11), users were more likely to engage in positive word-of-mouth behavior after incidents of PMI and LBS than other applications (F4). The difference was statistically significant. As much as $71 \%$ of positive PMI incidents reflected positive word-of-mouth, while the corresponding percentage for other applications was only 42. For other constructs within positive incidents, there were no statistically significant differences for application type.

Regarding F4, many users described PMI and LBS applications as novel and sophisticated ("[I liked] the new innovation;" "Cool, they invent everything nowadays"). It appeared to us that such perceptions of novelty and sophistication made it appealing for the users to communicate their incidents to others. For example, some of the users mentioned that novelty aspects of PMI are worth telling others. In some cases, users linked these aspects with references to fuzzy future behaviors ("It made me smile when I realized we can use [image recognition] technology in various situations"). However, we did not observe any specific link between novelty or sophistication and use continuance.

Concerning negative incidents (Table 12), users were more likely to quit using the application after PMI incidents than incidents with other applications ( 55 ). The difference for application type was statistically significant regarding both intended and actual use continuance. For negative word-of-mouth and complaints, there were no statistically significant differences for application type.

With F5, many of the negative PMI incidents were trials and tests that failed to prove the application functional or useful ("The application didn't [function as advertised]"). Even in the negative descriptions, the users reported that they were interested in the innovative potential of PMI, but often had no decent 
reason for continuing use after negative incidents ("Nice invention but useless"). In contrast, many of the descriptions concerning other applications refer to frequent streams of use situations, which users already consider useful.

\begin{tabular}{|c|c|c|c|c|c|c|}
\hline \multicolumn{7}{|c|}{ Table 11. Application Type and Positive Incidents } \\
\hline & \multicolumn{2}{|c|}{$\begin{array}{l}\text { Intended Behaviors } \\
\text { (Construct mean) }\end{array}$} & \multicolumn{4}{|c|}{$\begin{array}{c}\text { Actual Behaviors } \\
\text { (\% and } N \text { of respondents) }\end{array}$} \\
\hline & \multirow[t]{2}{*}{$\begin{array}{c}\text { Use } \\
\text { continuance }\end{array}$} & \multirow[t]{2}{*}{$\begin{array}{l}\text { Positive } \\
\text { word-of- } \\
\text { mouth }\end{array}$} & \multicolumn{2}{|c|}{$\begin{array}{l}\text { Entirely quit using } \\
\text { the app after the } \\
\text { experience }\end{array}$} & \multicolumn{2}{|c|}{$\begin{array}{l}\text { Told others about } \\
\text { the experience }{ }^{\star \star *}\end{array}$} \\
\hline & & & Yes & No & Yes & No \\
\hline PMI & 4.54 & 4.11 & $\begin{array}{c}7.0 \% \\
(21)\end{array}$ & $\begin{array}{l}93.0 \% \\
(281)\end{array}$ & $\begin{array}{c}71.3 \% \\
(209)\end{array}$ & $\begin{array}{c}28.7 \% \\
(84)\end{array}$ \\
\hline LBS & 4.65 & 4.23 & $\begin{array}{c}5.0 \% \\
(6)\end{array}$ & $\begin{array}{l}95.0 \% \\
(113)\end{array}$ & $\begin{array}{c}62.8 \% \\
(71)\end{array}$ & $\begin{array}{c}37.2 \% \\
(42)\end{array}$ \\
\hline $\begin{array}{l}\text { Other } \\
\text { applications }\end{array}$ & 4.49 & 3.96 & $\begin{array}{c}6.3 \% \\
(6)\end{array}$ & $\begin{array}{c}93.7 \% \\
(89)\end{array}$ & $\begin{array}{c}41.5 \% \\
(39)\end{array}$ & $\begin{array}{c}58.5 \% \\
(55)\end{array}$ \\
\hline Test result & $\begin{array}{c}\text { ANOVA, } \\
F(2,513) \\
=1.47, \mathrm{~N}=516, \\
p=0.231\end{array}$ & 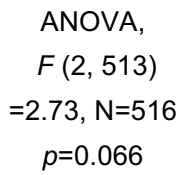 & $\begin{aligned} & X^{2}(2 \\
= & 0.52\end{aligned}$ & $\begin{array}{l}516) \\
0.770\end{array}$ & $\begin{aligned} & X^{2}(2 \\
= & 27.5\end{aligned}$ & $\begin{array}{l}=500) \\
=0.000\end{array}$ \\
\hline
\end{tabular}

\begin{tabular}{|c|c|c|c|c|c|c|c|c|c|}
\hline \multicolumn{10}{|c|}{ Table 12. Application Type and Negative Incidents } \\
\hline & \multicolumn{3}{|c|}{$\begin{array}{l}\text { Intended Behaviors } \\
\text { (Construct mean) }\end{array}$} & \multicolumn{6}{|c|}{$\begin{array}{c}\text { Actual Behaviors } \\
\text { (\% and } N \text { of respondents) }\end{array}$} \\
\hline & \multirow[t]{2}{*}{$\begin{array}{c}\text { Use } \\
\text { continuance * }\end{array}$} & \multirow[t]{2}{*}{$\begin{array}{l}\text { Negative } \\
\text { word-of- } \\
\text { mouth }\end{array}$} & \multirow[t]{2}{*}{ Complaints } & \multicolumn{2}{|c|}{$\begin{array}{l}\text { Entirely quit using } \\
\text { the app because of } \\
\text { the experience * }\end{array}$} & \multicolumn{2}{|c|}{$\begin{array}{l}\text { Told others about } \\
\text { the experience }\end{array}$} & \multicolumn{2}{|c|}{$\begin{array}{c}\text { Made a complaint } \\
\text { about the } \\
\text { experience }\end{array}$} \\
\hline & & & & Yes & No & Yes & No & Yes & No \\
\hline PMI & 2.19 & 3.06 & 2.54 & $\begin{array}{c}67.4 \% \\
(31)\end{array}$ & $\begin{array}{c}32.6 \% \\
(15)\end{array}$ & $\begin{array}{c}51.1 \% \\
(23)\end{array}$ & $\begin{array}{c}48.9 \% \\
(22)\end{array}$ & $\begin{array}{c}6.5 \% \\
(3)\end{array}$ & $\begin{array}{c}93.5 \% \\
(43)\end{array}$ \\
\hline LBS & 2.86 & 2.51 & 2.46 & $\begin{array}{c}42.9 \% \\
(6)\end{array}$ & $\begin{array}{c}57.1 \% \\
(8)\end{array}$ & $\begin{array}{c}71.4 \% \\
(10)\end{array}$ & $\begin{array}{c}28.6 \% \\
(4)\end{array}$ & $\begin{array}{c}0.0 \% \\
(0)\end{array}$ & $\begin{array}{c}100 \% \\
(14)\end{array}$ \\
\hline $\begin{array}{l}\text { Other } \\
\text { applications }\end{array}$ & 2.77 & 2.80 & 2.44 & $\begin{array}{c}37.0 \% \\
(10)\end{array}$ & $\begin{array}{c}63.0 \% \\
(17)\end{array}$ & $\begin{array}{c}38.5 \% \\
(10)\end{array}$ & $\begin{array}{c}61.5 \% \\
(16)\end{array}$ & $\begin{array}{c}7.4 \% \\
(2)\end{array}$ & $\begin{array}{c}92.6 \% \\
(25)\end{array}$ \\
\hline Test result & $\begin{array}{c}\text { ANOVA, } \\
F(2,81) \\
=3.34, N=84, \\
p=0.040\end{array}$ & $\begin{array}{c}\text { ANOVA, } \\
F(2,83) \\
=1.57, N=86, \\
p=0.214\end{array}$ & $\begin{array}{c}\text { ANOVA, } \\
F(2,80) \\
=0.06, \mathrm{~N}=83, \\
p=0.942\end{array}$ & $\begin{aligned} & X^{2}(2 \\
= & 7.15\end{aligned}$ & $\begin{array}{l}=87) \\
=0.028\end{array}$ & $\begin{aligned} & X^{2}(2 \\
= & 3.97\end{aligned}$ & $\begin{array}{l}=85) \\
0.138\end{array}$ & $\begin{array}{r}\text { N/A: } 5 \\
\text { have } \\
\text { count }\end{array}$ & $\begin{array}{l}\text { of cells } \\
\text { ected } \\
\text { than } 5\end{array}$ \\
\hline
\end{tabular}




\section{Discussion}

\section{Theoretical Implications}

As illustrated in Figure 3, the existing approaches have examined the relationship between the situational context and post-experience behaviors on an abstract level, but this study contributes to current knowledge by uncovering and explaining diverse relationships of specific situational characteristics and different types of post-experience behaviors. With the help of the empirical evidence, we developed a research model that illustrates these specific relationships and their reasons. Our model assists researchers in starting to break down the very complex and multidimensional phenomenon of mobile usage. Since the use of mobile devices and applications occurs in many unique situational surroundings, we need to know more about how the great variety of different use contexts links with user behaviors. This is the need we attempted to answer by conducting this study.

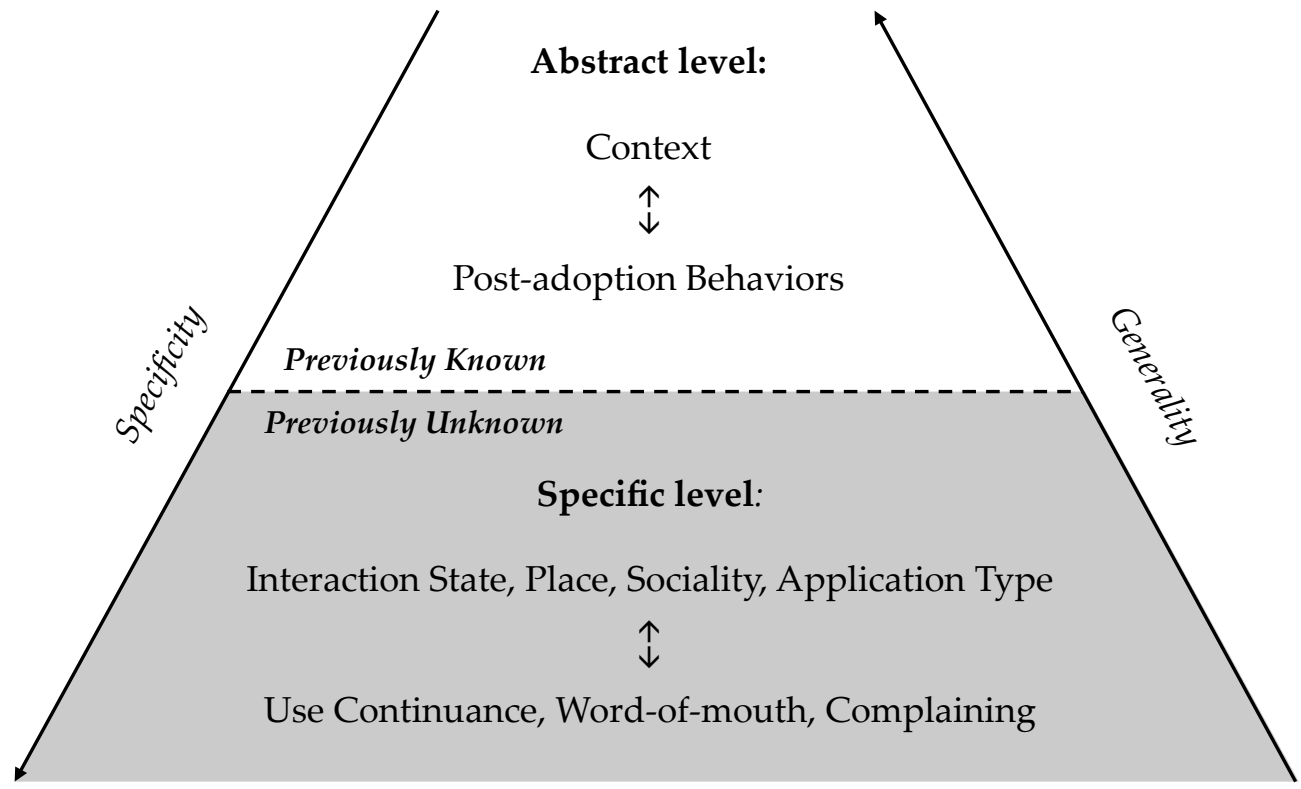

Figure 3. Our Contribution to Existing Knowledge

Since all critical incidents do not demand attention from the researchers or management staff (Edvardsson \& Strandvik 2000), our results can assist both researchers and practitioners in distinguishing which critical incidents are more crucial than others and that require managerial action in particular. We assume that the most crucial ones are those critical incidents after which the users more likely engage in positive or negative post-experience behaviors. Such incidents can be sorted out by situational characteristics: according to our analyses, the most crucial incidents regarding post-experience 
behaviors are positive task-oriented incidents, positive outdoor or vehicle incidents, negative indoor incidents, positive PMI and LBS incidents, and negative PMI incidents.

Based on our results regarding interaction state, users more likely engage in positive behaviors after positive critical incidents that involve a clear task than after those without a task. This finding is new but consistent with the reversal theory, as it suggest that users think about the future in a task-oriented state and the present in an activity-oriented state (Apter 1989; Deng \& Poole 2010). As a result of this new understanding about interaction state, we suggest that researchers should look closely at use motivation on a situational level. In this sense, we feel that it is limiting for researchers to treat motivation and user behavior only as static phenomena; instead, they should be seen as dynamic phenomena that is adaptable to each situation. Further, our results indicate that there is research potential in understanding the customization of mobile and other IS applications by the users' dynamic interaction state, instead of the traditional investigation and appliance of static user-profiling.

In terms of place, our results complement prior mobile studies that have applied different categorizations for understanding the influence of place, such as suburban versus urban location (Xu \& Yuan 2009) and home versus office or school setting (Liang \& Yeh 2011). We found that users were more likely to continue use after positive critical incidents and less likely to engage in negative behaviors after negative critical incidents that happened outdoors or in vehicles. These findings are partly in line with previous studies that emphasized unanticipated needs, a lack of alternatives, and uncertain conditions (Gummerus \& Pihlström 2011; Mallat 2007; Mallat et al. 2008, 2009), but our results carry previous insights further by specifying such aspects to indoor, outdoor, and vehicle environments. This increased level of specificity assists researchers in recognizing the differences related to physical surroundings and opens possibilities to investigate even more specific dimensions of places indoors (e.g., shops versus homes) and outdoors (e.g., parks versus city streets).

For the level of sociality, we found no statistically significant differences. This study adds to current knowledge by contradicting some of the prior assumptions: even though prior studies have underlined shared experiences and co-experiences (Battarbee \& Koskinen 2005; Teevan et al. 2011), our results reveal that post-experience behaviors do not seem to depend on whether or not the user undergoes the critical incident alone. Our results therefore extend current knowledge by indicating that the level of sociality might link with users' experiences in situ but not necessarily with their post-experience behaviors. Researchers should acknowledge this potential distinction when developing theories about sociality, user perceptions, and behavior. However, the issue should be confirmed with future studies involving a larger set of negative incidents and more categories for different levels of sociality.

Regarding application type, we found that users are more likely to communicate positive word-ofmouth after positive PMI and LBS incidents in comparison to other mobile Internet applications. The finding that perceptions of novelty and sophistication link with word-of-mouth is partially supported by Berger and Schwartz (2011), who have found that more interesting products receive more immediate 
word-of-mouth. With PMI-related mobile applications, recent studies have found novelty and innovativeness to reflect positive user perceptions (Rukzio et al. 2007; Salo et al. 2013), but our results specify that the difference relates only to word-of-mouth, not use continuance. The finding suggest that while the users' fascination with novel application types may increase visibility and foster initial adoption, it may not be enough to convert users from initial experimenters to continuing, frequent users. In future theorizing, it should be noted that fascination and novelty of new applications might relate differently to initial adoption than to use continuance.

\section{Practical Implications}

From a managerial perspective3, outdoor and vehicle settings and other relatively special environments can often be considered as lower risk-higher reward environments from the standpoint of postexperience behaviors. Hence, application providers could reach for the potential rewards by initially testing and making their applications function as well as possible outdoors and in vehicles and then by encouraging users to employ the applications in those environments (assuming that their applications are not purposely restricted to indoor usage). On the other hand, indoor incidents reflect greater risks, so providers should systematically analyze potential indoor-failures to prevent them.

As far as application types are concerned, there are high rewards and high risks for new and innovative applications such as PMI. By ensuring the readiness, functionality, and quality of such applications right from their launch, application providers could increase the odds for positive critical incidents as well as positive word-of-mouth and, thus, acquire new users. To address the high risks for unfavorable behaviors, providers should do their best to avoid negative critical incidents of PMI. In cases of failures, application providers could encourage users to continue using the applications even after negative incidents by offering service recovery or creating at least a realistic image of long-lasting value in addition to plain novelty or sophistication.

Regarding the interaction state, task-oriented incidents may involve more rewards but only little or no difference in risks compared to activity-oriented incidents. To reach these rewards, application providers could exemplify crystal-clear use situations in which their applications could be used for getting something concrete done. However, nearly one-third of the positive critical incidents were activityoriented, and many of these incidents involved positive post-experience behaviors, so activity-oriented incidents also should be promoted.

Only a tiny share of all reported negative critical incidents (6\%) were linked to actual complaints. The percentage is notably lower than what Meuter et al. (2000) have found with self-service technologies (51\%). With a low number of complaints, there are fewer possibilities for service recovery, which shapes a concern-especially for e-service providers (Chea \& Luo 2008). This indicates that application providers

3 We believe that the applications are the core causes of the incidents, even though mobile applications may require interplay with other mobile components such as network connectivity. Therefore, we present practical implications particularly for the application providers. 
could improve the possibilities for service recovery by making feedback options easily available for their users. Easy feedback options may encourage users to complain about their negative incidents directly to application providers instead of sharing their worries with other individuals in the form of negative wordof-mouth. Such a simple feature could also sometimes soften a prospective negative critical incident and transform it into an ordinary experience.

\section{Limitations and Future Research}

This study contains some limitations. First, our empirical evidence included a great deal of positive critical incidents, but there could have been more negative critical incidents. A few of the categories of negative incidents consisted of a rather small number of cases, which may prevent the generalization of the findings for those particular categories, even though the number of negative incidents allowed us to run most statistical analyses. Second, we aimed to combine the most essential aspects of the situational context in the four characteristics, but our combination did not cover all possible aspects. Third, the length of time since the incident occurred might have affected actual behaviors. However, we measured the times when the incident had taken place and checked that the situational characteristics had not been centered around any specific time frame. Fourth, compared to the target population, there are some slight misrepresentations in our sample. As the respondents between the ages of 45 to 64 are mildly underrepresented, it may indicate that, in our sample, there might be fewer users who persistently stick with the existing application even after negative incidents. Also, the slight overrepresentation of the respondents between the ages of 25 to 34 may mean that our sample might emphasize users who like to try several applications and easily move to the next one, thus perhaps discontinuing the use of the previous application more often than others. Fifth, there is "the tension between what people report they do and what they actually do" (van der Heijden 2012, p. 349). We suggest that readers be careful when interpreting the findings: intention measures give indications about users' post-experience attitudes and future behavior, while our actual behavior measures are there to show what already has happened. Finally, the reported incidents referred to a diverse range of applications, but some of the applications were relatively frequent. Even though such applications may be more commonly used or memorable, the quantity of their appearance might have affected the findings by emphasizing certain aspects. In spite of these limitations, this study provides valuable new insights on the situational characteristics and user behaviors after critical mobile incidents.

This study also opens new opportunities for future research. First, in our statistical analysis, we have found specific relationships between the situational characteristics and post-experience behaviors, but we suggest that researchers statistically conclude the causality of these relationships in the future. Second, it would be beneficial to study critical incidents that occur in vehicles, since we managed to present interesting initial findings but our empirical evidence was limited in terms of those special incidents. The context of vehicles should be taken into account because it differs from other use environments and it is where users are relying on mobile applications more and more often. Third, some of the reported 
incidents reflected first-time usage but others were related to repeated usage. It would be interesting to study if users' first-time experiences versus repeated experiences have different relationships with postexperience behaviors. ${ }^{4}$ Finally, as we did not find statistical significance regarding the level of sociality, we encourage researchers to investigate the issue with a larger set of negative incidents.

${ }_{4}$ We thank the review team for this research idea. 


\section{References}

Anckar, B \& D'Incau, D 2002, 'Value Creation in Mobile Commerce: Findings From a Consumer Survey', Journal of Information Technology Theory and Application, vol. 4, no. 1, pp. 43-64.

Apter, MJ 1989 'Reversal Theory: A New Approach to Motivation, Emotion and Personality', Anuario de Psicología, vol. 42, no. 3, pp. 17-29.

Battarbee, K \& Koskinen, I 2005, 'Co-Experience: User Experience as Interaction', CoDesign, vol. 1, no. 1, pp. 5-18.

Belk, RW. 1975, 'Situational Variables and Consumer Behavior', Journal of Consumer Research, vol. 2, no. 3, pp. 157-164.

Berger, J \& Schwartz, E 2011, 'What Drives Immediate and Ongoing Word of Mouth?' Journal of Marketing Research, vol. 48, no. 5, pp. 869-880.

Bhattacherjee, A 2001, 'Understanding Information Systems Continuance: An Expectation-Confirmation Model', MIS Quarterly, vol. 25, no. 3, pp. 351-370.

Bitner, MJ, Booms, BH \& Tetreault, MS 1990, 'The Service Encounter: Diagnosing Favorable and Unfavorable Incidents', Journal of Marketing, vol. 54, no. 1, pp. 71-84.

Bougie, R, Pieters, R \& Zeelenberg, M 2003, 'Customers Don't Come Back, They Get Back: Experience and Behavioral Implications of Anger Dissatisfaction in Services', Journal of the Academy Marketing Science, vol. 31, no. 4, pp. 377-393.

Cenfetelli, RT 2004, 'Inhibitors and Enablers as Dual Factor Concepts in Technology Usage', Journal of the Association for Information Systems, vol. 5, no. 11-12, pp. 472-492.

Chea, S \& Luo, M 2008, 'Post-Adoption Behaviors of E-Service Customers: The Interplay of Cognition and Emotion', International Journal of Electronic Commerce, vol. 12, no. 3, pp. 29-56.

Coursaris, CK \& Kim, DJ 2011, 'A Meta-Analytical Review of Empirical Mobile Usability Studies', Journal of Usability Studies, vol. 6, no. 3, pp. 117-171.

Deng, L \& Poole, MS 2010, 'Affect in Web interfaces: A Study of the Impacts of Web Page Visual Complexity and Order', MIS Quarterly, vol. 34, no. 4, pp. 711-730.

Edvardsson, B \& Strandvik, T 2000, 'Is a Critical Incident Critical for a Customer Relationship?' Managing Service Quality, vol. 10, no. 2, pp. 82-91.

Edvardsson, B \& Roos, I 2001, 'Critical Incident Techniques: Towards a Framework for Analysing the Criticality of Critical Incidents', International Journal of Service Industry Management, vol. 12, no. 3, pp. 251-268.

Flanagan, JC 1954, 'The Critical Incident Technique', Psychological Bulletin, vol. 51, no. 4, pp. 327-358. Forlizzi, J \& Battarbee, K 2004, 'Understanding Experience in Interactive Systems', Proceedings of the 5 th Conference on Designing Interactive Systems: Processes, Practices, Methods \& Techniques. ACM, New York, pp. 261-268.

Gremler, DD 2004, 'The Critical Incident Technique in Service Research', Journal of Service Research, vol. 7 , no. 1, pp. 65-89. 
Grove, SJ \& Fisk, RP 1997, 'The Impact of Other Customers on Service Experiences: A Critical Incident Examination of 'Getting Along”, Journal of Retailing, vol. 73, no. 1, pp. 63-85.

Gummerus, J \& Pihlström, M 2011, 'Context and Mobile Services' Value-In-Use', Journal of Retailing and Consumer Services, vol. 18, no. 6, pp. 521-533.

Hassenzahl, M 2003, 'The Thing and I: Understanding the Relationship Between User and Product', in MA Blythe, K Overbeeke, AF Monk \& PC Wright (eds), Funology: From Usability to Enjoyment, Kluwer Academic Publishers, Dordrecht, pp. 31-42.

Hassenzahl, M, Kekez, R \& Burmester, M 2002, 'The importance of a software's pragmatic quality depends on usage modes', Proceedings of the 6th International Conference on Work With Display Units, pp. 275-276.

Holloway, BB \& Beatty, SE 2008, 'Satisfiers and Dissatisfiers in the Online Environment: A Critical Incident Assessment', Journal of Service Research, vol. 10, no. 4, pp. 347-364.

Hong, S-J \& Tam, KY 2006, 'Understanding the Adoption of Multipurpose Information Appliances: The Case of Mobile Data Services', Information Systems Research, vol. 17, no. 2, pp. 162-179.

Jacucci, G, Oulasvirta, A \& Salovaara, A 2007, 'Active Construction of Experience Through Mobile Media: A Field Study with Implications for Recording and Sharing', Personal and Ubiquitous Computing, vol. 11, no. 4, pp. 215-234.

Johnston, R 1995, 'The Zone of Tolerance: Exploring the Relationship Between Service Transactions and Satisfaction with the Overall Service', International Journal of Service Industry Management, vol. 6 , no. 2, pp. 46-61.

Jumisko-Pyykkö, S \& Vainio, T 2010, 'Framing the Context of Use for Mobile HCI', International Journal of Mobile Human Computer Interaction, vol. 2, no. 4, pp. 1-28.

Lang, B 2009, 'Toward a Better Measure of Positive and Negative Word of Mouth: A Replication and Extension and a Case for Content Validity', Australia and New Zealand Marketing Academy.

Lee, I, Kim, J \& Kim, J 2005, 'Use Contexts for the Mobile Internet: A Longitudinal Study Monitoring Actual Use of Mobile Internet Services', International Journal of Human-Computer Interaction, vol. 18, no. 3, pp. 269-292.

Liang, T-P \& Yeh, Y-H 2011, 'Effect of use contexts on the continuous use of mobile services: the case of mobile games', Personal Ubiquitous Computing, vol. 15, no. 2, pp. 187-196.

Liu, Y \& Li, H 2011, 'Exploring the impact of use context on mobile hedonic services adoption: An empirical study on mobile gaming in China', Computers in Human Behavior, vol. 27, no. 2, pp. 890898.

Mallat, N 2007, 'Exploring consumer adoption of mobile payments - A qualitative study', Journal of Strategic Information Systems, vol. 16, no. 4, pp. 413-432.

Mallat, N, Rossi, M, Tuunainen, VK \& Öörni, A 2008, 'An empirical investigation of mobile ticketing service adoption in public transportation', Personal Ubiquitous Computing, vol. 12, no. 1, pp. 57-65.

Mallat, N, Rossi, M, Tuunainen, VK \& Öörni, A 2009, 'The Impact of Use Context on Mobile Services Acceptance: The Case of Mobile Ticketing', Information and Management, vol. 46, no. 3, pp. 190-195. 
Massad, N, Heckman, R \& Crowston, K 2006, 'Customer Satisfaction with Electronic Service Encounters', International Journal of Electronic Commerce, vol. 10, no. 4, pp. 73-104.

Mathieson, K 1991, 'Predicting User Intentions: Comparing the Technology Acceptance Model with the Theory of Planned Behavior', Information Systems Research, vol. 2, no. 3, pp. 173-191.

Meuter, ML, Ostrom, AL, Roundtree, RI \& Bitner, MJ 2000, 'Self-Service Technologies: Understanding Customer Satisfaction with Technology-Based Service Encounters', Journal of Marketing, vol. 64, no. 3, pp. 50-64.

Morgan Stanley Research. 2011, 'Tablet Demand and Disruption. Mobile Users Come of Age.' Morgan Stanley Blue Paper.

Nunnally, JC \& Bernstein, IH 1994. Psychometric Theory. New York: McGraw-Hill.

Payne, A, Storbacka, K \& Frow, P 2008, 'Managing the Co-creation of Value', Journal of the Academy of Marketing Science, vol. 36, no. 1, pp. 83-96.

Rukzio, E, Broll, G, Leichtenstern, K \& Schmidt, A 2007, 'Mobile Interaction with the Real World: An Evaluation and Comparison of Physical Mobile Interaction Techniques', in B Schiele, A Buchmann, AK Dey, H Gellersen \& B De Ruyter (eds), Proceedings of the 2007 European Conference on Ambient Intelligence, Springer-Verlag, Berlin, pp. 1-18.

Salo, M 2013, 'Sources of Dissatisfaction: Mobile Interaction with the Real World and Other Mobile Internet Applications', Proceedings of 46th Hawaii International Conference on System Sciences, pp. 1113-1122.

Salo, M, Olsson, T, Makkonen, M, Hautamäki, A \& Frank, L 2013, 'Consumer Value Of Camera-Based Mobile Interaction with the Real World', Pervasive and Mobile Computing, vol. 9, no. 2, pp. 258-268. Sarker, S, Xiao, X \& Beaulieu, T 2012, 'Toward an Anatomy of 'Successful' Qualitative Research Manuscripts in IS: A Critical Review and Some Recommendations', Proceedings of the 33rd International Conference on Information Systems.

Serenko, A 2006, 'The Use of Interface Agents for Email Notification in Critical Incidents', International Journal of Human-Computer Studies, vol. 64, no. 11, pp. 1084-1098.

Serenko, A \& Stach, A 2009, 'The Impact of Expectation Disconfirmation on Customer Loyalty and Recommendation Behavior: Investigating Online Travel and Tourism Services', Journal of Information Technology Management, vol. 20, no. 3, pp. 26-41.

Serenko, A \& Turel, O 2010, 'Rigor and Relevance: The Application of the Critical Incident Technique to Investigate Email Usage', Journal of Organizational Computing and Electronic Commerce, vol. 20, no. 2, pp. 182-207.

Statistics Finland. 2012, 'Tieto- ja viestintätekniikan käyttö 2011', Tiede, teknologia ja tietoyhteiskunta. Helsinki: Tilastokeskus.

Sweeney, JC \& Lapp, W 2004, 'Critical Service Quality Encounters on the Web: An Exploratory Study', Journal of Services Marketing, vol. 18, no. 4, pp. 276-289. 
Teevan, J, Karlson, A, Amini, S, Bernheim Brush, AJ \& Krumm, J 2011, 'Understanding the Importance of Location, Time, and People in Mobile Local Search Behavior', Proceedings of the 13th International Conference on Human Computer Interaction with Mobile Devices and Services, pp. 77-80.

van der Heijden, H 2012. 'User acceptance of electronic commerce: Contributions from the Bled eConference,' BLED 2012, Special Issue, Paper 11.

van der Heijden, H, Ogertschnig, M \& van der Gast, L 2005, 'Effects of Context Relevance and Perceived Risk on User Acceptance of Mobile Information Services', Proceedings of European Conference on Information Systems.

Venkatesh, V, Thong, JYL \& Xu, X 2012, 'Consumer Acceptance and Use of Information Technology: Extending the Unified Theory of Acceptance and Use of Technology', MIS Quarterly, vol. 36, no. 1, pp. 157-178.

Venkatesh, V, Thong, JYL, Chan, FKY, Hu, PJH \& Brown, S 2011, 'Extending the Two-Stage Information Systems Continuance Model: Incorporating UTAUT Predictors and the Role of Context', Information Systems Journal, vol. 21, no. 6, pp. 527-555.

Wang, L \& Yi, Y 2012, 'The Impact of Use Context on Mobile Payment Acceptance: An Empirical Study in China', in A Xie \& X Huang (eds), Advances in Computer Science and Education, Springer-Verlag, Berlin, AISC 140, pp. 293-299

Webster, J \& Watson, RT 2002, 'Analyzing the Past to Prepare for the Future: Writing a Literature Review', MIS Quarterly, vol. 26, no. 2, pp. xiii-xxiii.

$\mathrm{Xu}, \mathrm{Z} \&$ Yuan, Y 2009, 'The impact of context and incentives on mobile service adoption', International Journal of Mobile Communications, vol. 7, no. 3, pp. 363-381.

Yang, S, Lu, Y, Gupta, S \& Cao, Y 2012, 'Does Context Matter? The Impact of Use Context on Mobile Internet Adoption', International Journal of Human-Computer Interaction, vol. 28, no. 8, pp. 530541.

Zeithaml, VA, Berry, LL \& Parasuraman, A 1996, 'The Behavioral Consequences of Service Quality', Journal of Marketing, vol. 6o, no. 2, pp. 31-46.

Zhou, T 2011, 'An Empirical Examination of Users' Post-Adoption Behaviour of Mobile Services', Behaviour \& Information Technology, vol. 30, no. 2, pp. 241-250. 


\section{Appendix A: Examples of positive \& negative critical mobile incidents (from our empirical evidence)}

\section{Positive}

The user was alone downtown, in an outdoor location. He used an application that recognizes objects on the sky.

"I noticed a bright object in the sky, which is quite rare in the city center because of the city lights. I knew from the brightness of the object that it was probably a planet, but I wasn't sure which one, so I wanted to check.

The application can be used to recognize stars and objects by simply 'pointing' the mobile device toward the object. The application recognizes the motion and direction with different sensors and shows on the screen what should be in the sky so that the user can conclude which object it is.

I was surprised how well the application functioned, since I hadn't used it before. Afterwards, it was nice to discuss the phenomenon with my friends.

[As a consequence of the incident, I had] a curious feeling."

\section{Negative}

The user was having an outdoor picnic with his friends. He used a wine guide application that can scan barcodes from bottles.

"At the picnic, I wanted to store information about a wine that my friend recommended. I scanned the barcode of the wine bottle with the application's own barcode reader so that I could automatically receive the information on the screen.

The scanning didn't work. Despite the guiding lines on the screen ('align the barcode in this area'), the application didn't provide any feedback about my attempt and didn't report any kind of activity.

I felt embarrassed [when I attempted this task], looking stupid with my new and expensive smart phone. The others were not convinced." 


\section{Appendix B: Explanatory characteristics - category descriptions and examples regarding qualitative analysis}

The related analysis, which was done after the quantitative part, aimed to identify explanatory tendencies for the five statistically significant relationships.

Finding $(F)$ and category Description Example: Quotation Excerpt

F1: Positive, task-oriented incidents

Concrete task

Foreseeable task
The user gets something concrete done with the application.

The user gets something foreseeable done with the application.
"I found a nice [restaurant with the help of the application]"

"[The application] did what I had planned"

F2: Positive, outdoor and vehicle incidents

Instant need

Special environment
The user fulfills a momentary need with the application (often with no other alternatives available).

The application functions in an environment which the user considers somehow special.
"In the forest... an immediate, surprising need appeared. [The solution] was easier and faster than I could've wished"

"...on an island... it works as good as with desktop computer at home"

F3: Negative, indoor incidents

Established expectations

Low uncertainty
The user expects the application to function based on prior experience, but the application fails.

The user has no concerns on whether the application would function, but the application fails.
"In regular use of [the application]... it lagged"

"I used the application normally but it didn't work"

F4: Positive, PMI and LBS

incidents

Novelty

Sophistication
The newness of the application fascinates the user.

The user appreciates the (technical) advancement of the application.
"Pretty amazing application, it was the newest of new"

“...once again we've taken a big step toward pervasive technology..."

F5: Negative, PMI incidents

Lack of functionality

Lack of usefulness
The application fails to prove its functionality for the user.

The application fails to prove its usefulness for the user.
"First the [barcode] scanning failed and then it brought a false result"

"Another pointless application" 